\title{
Sambia succinica, a crown group tenthredinid from Eocene Baltic amber (Hymenoptera: Tenthredinidae)
}

\author{
Lars Vilhelmsen ${ }^{\mathrm{a},{ }^{*}}$ and Michael S. Engel ${ }^{\mathrm{b}}$ \\ ${ }^{a}$ Natural History Museum of Denmark, University of Copenhagen, Universitetsparken 15, DK-2100 \\ Copenhagen, Denmark \\ ${ }^{\mathrm{b}}$ Division of Entomology (Paleoentomology), Natural History Museum and Department of Ecology \\ \& Evolutionary Biology, 1501 Crestline Drive, Suite 140, University of Kansas, Lawrence \\ KS 66045, USA \\ *Corresponding author, e-mail: lbvilhelmsen@snm.ku.dk \\ Published 17 December 2012
}

\begin{abstract}
Sambia succinica gen. et sp.n. from Eocene Baltic amber is described and illustrated. It is apparently the first amber fossil that can be definitively assigned to Tenthredininae. It displays two diagnostic forewing characters for this subfamily: having a bend distally in vein $R$ and the junctions of veins $M$ and $R s+M$ with vein $\mathrm{R}$ being some distance from each other. The variance and possible transitions between the anal vein configurations among the genera in Tenthredininae is briefly discussed.
\end{abstract}

\section{Keywords}

amber inclusion, sawfly, Tertiary, Eocene, taxonomy

\section{Introduction}

Tenthredinidae is the largest family of non-apocritan Hymenoptera by far, comprising more than 5500 described species (Huber 2009; Taeger \& Blank 2010). Together with five other families they comprise the Tenthredinoidea or true sawflies. The larvae of the members of the superfamily are all herbivores and most are external feeders on green parts of angiosperms; however, other host plants and feeding modes (e.g., leafrolling, leafmining, or galling in leaves, buds and shoots; see Nyman et al. 1998, 2000) do occur. Recent comprehensive treatments of the phylogeny of the basal hymenopteran lineages, while providing strong support for the Tenthredinoidea, have consistently failed to retrieve the Tenthredinidae as monophyletic (Vilhelmsen 2001; Schulmeister 2003; Ronquist et al. in press). Indeed, a thorough, phylogenetically based revision of this family and its constituent subclades is highly needed. Of the six subfamilies recognized within the Tenthredinidae, Tenthredininae is the largest, with approx. 1700 
described species comprising about $30 \%$ of the known diversity of the family (Taeger \& Blank 2010).

The fossil record of Tenthredinoidea is substantial; putative stemgroup taxa are known from the Late Jurassic and Early Cretaceous, whereas fossils that can be placed in extant families do not occur until the Tertiary (see Grimaldi \& Engel 2005 and references therein). The majority of tenthredinoid fossils known are compressions, only Argidae and Diprionidae being represented in Tertiary amber so far (Grimaldi \& Engel 2005). Brischke (1886) mentioned Tenthredo in a list of genera occurring in Baltic amber (a record repeated by Handlirsch (1907), Statz (1936), Larsson (1978), and Spahr (1987)), but the whereabouts of the material is unknown as well as the veracity of his identification. In this paper, we describe an adult female from Eocene Baltic amber (Lutetian stage, ca. 45 million years ago), which we tentatively place in the subfamily Tenthredininae. We place the fossil taxon in a new genus, since comparison with a range of representatives of extant members of the Tenthredininae and the descriptions of most of the extinct ones did not reveal any obvious candidate for placement in an existing genus.

\section{Materials and Methods}

The specimen is included in a piece of middle Eocene (Lutetian) Baltic amber. The age, paleofauna, and origin of Baltic amber have been reviewed by Weitschat and Wichard $(2002,2010)$ and Grimaldi and Engel (2005).

\section{Extant material for comparison}

The following extant taxa were all dissected and preserved in glycerol as part of an ongoing project aiming to resolve the phylogeny of the Tenthredinidae, its constituent subgroups and its closest relatives: Aglaostigma fulvipes (Scopoli, 1763); Corymbas koreana Konow, 1903; Filacus albipes (Provancher, 1895); Lagium atroviolaceum (Norton, 1860); Leucopelmonus annulicornis (Harrington, 1893); Macrophya duodecimpunctata (Linnaeus, 1758); Pachyprotasis rapae (Linnaeus, 1767); Perineura rubi (Panzer, 1805); Rhogogaster viridis (Linnaeus, 1758); Sciapteryx consobrina (Klug, 1816); Siobla sturmii (Klug, 1817); Tenthredo (T.) scrophulariae Linnaeus, 1758; Tenthredo (Elinora) koehleri Klug, 1817; Tenthredopsis ornata (Audinet-Serville, 1823); Zaschizonyx montana (Cresson, 1865). In addition, comparison was made with the following taxa, which were observed from entire pinned specimens deposited in the Natural History Museum, London: Armitarsus punctifemoratus Malaise, 1931; Conaspidia guttata (Matsumura, 1912); Conaspidia hyalina Sato, 1933; Colochelyna magrettii Konow, 1898; Tenthredo (Elinora) amasiensis (Kriechbaumer, 1869); Tenthredo (Tenthredo) arctica (Thomson, 1870); Tenthredo (Propodea) fentoni W.F. Kirby, 1882; Tenthredo (Tenthredina) fortunii W.F. Kirby, 1882; Tenthredo (Peus) priva (Konow, 1903); Tenthredo sibirica (Kriechbaumer, 1869); Tenthredo (Propodea) spinosa Cameron, 1899; Tenthredo (Metallopeus) splendida (Konow, 1907); Tyloceridius dorsatus (Mocsáry, 1883). 


\section{Fossil taxa considered}

Taeger et al. (2010) listed 19 fossil species under Tenthredininae, all of which are compression fossils with little to no relief. These species are summarized in Table 1, noting those of which the descriptions were consulted and compared with the current amber inclusion. Should Piton's (1940) species be assigned correctly, it would then represent the oldest record of the subfamily, predating the current fossil by $6-10$ million years.

\section{Examination and imaging}

The amber fossil and the dissected extant taxa were examined under a Leica MZ APO dissecting stereomicroscope. The photographic illustrations were compiled from stacks of images produced with a Leica DFC 420 digital camera and integrated with Leica software. The wings of extant taxa imaged in Figs 5-8 were slide mounted in glycerol prior to imaging.

\section{Systematic Paleontology}

Family Tenthredinidae Leach

Subfamily Tenthredininae Leach

\section{Sambia gen.n.}

Type species

Sambia succinica sp.n.

\section{Diagnosis}

The new genus can be recognized by the following unique combination of characters: clypeus only slightly incurved; inner margins of compound eyes parallel; antenna subclavate, with nine antennomeres; occipital carina present dorsally, absent laterally; inner margins of propleura abutting; metatibial spur one-third length of metabasitarsus; metabasitarsus longer than tarsomeres 2-4; forewing with bend in $\mathrm{R}$ distal; junction of $\mathrm{M}$ and $\mathrm{Rs}+\mathrm{M}$ with $\mathrm{R}$ some distance from each other; cell $1 \mathrm{RS}$ wider than 2RS; insertion of cu-a on Cu1 one-third from base; 1a distal, oblique.

\section{Etymology}

The new genus-group name honors the Old Prussian tribe of the Sambians who occupied Sambia (Samland/the Sambian Peninsula) where much Baltic amber historically has originated. The tribe was active in the amber trade prior to being conquered by the Teutonic Knights in the $13^{\text {th }}$ Century (Wikipedia). The name is feminine. 
Sambia succinica sp.n. (Figs 1-4)

Specimen provenance

Holotype. The holotype specimen has the label: 'AMBER: BALTIC / Middle Eocene (Lutetian) / Blau Erde, Northern Europe / KU-NHM-ENT, B-145'. It is deposited in the Division of Entomology, Natural History Museum, University of Kansas, Lawrence, KS, USA.

\section{Diagnosis}

As for the genus (see above).

\section{Description}

Female. Specimen mostly intact, except dorsally where it is exposed and eroded, removing most of mesonotum (see Fig. 4, right). Amber matrix mostly clear, with few cracks; small occlusions present at mouthparts and ovipositor. Body length as preserved 5.6 $\mathrm{mm}$, forewing length $4.8 \mathrm{~mm}$, head width $1.7 \mathrm{~mm}$. Head. Broad; compound eyes slightly converging, cuticular covering missing from central part of compound eyes; ocelli placed in obtuse triangle (Fig. 2); clypeus slightly incurved; occipital carina developed dorsally (Fig. 2), but apparently not laterally; frons, gena, vertex, and occiput covered with short, erect setae. Antenna with nine antennomeres (Fig. 1; left missing apical antennomere); scapus and pedicellus short, latter slightly longer than broad; antennomere 3 longest, approximately 1.5-times longer than antennomere 4; antennomeres 5-9 broader than antennomeres $1-4$, tapering slightly towards antennomere 9; antennomeres 6-9 each shorter than antennomere 5, subequal in length. Features of mouthparts hard to observe; maxillary palp with six palpomeres, labial palp with four. Thorax. Pronotum flat, closely abutting mesopleuron, with incurvation for anterior thoracic spiracle (Fig. 1); propleura mostly hidden, medioventral margins abutting for some distance; two apical protibial spurs, anterior spur (calcar) longer, slightly curved and bifid at tip. Mesonotum destroyed (see above); postspiracular sclerite present, prepectus not observed; posterior thoracic spiracle not observed, slight swelling/lobe present at usual position of spiracle (Fig. 1); other features, including sculpture, impossible to observe on meso- and metapleuron; two apical mesotibial spurs of subequal length. Metanotum covered by wings; metatibia significantly longer than metafemur (Fig. 1), with two apical spurs of equal length and not much longer than width of metatibia (Fig. 3); metatarsomeres 1-4 with distinct pulvilli, metabasitarsomere approximately equal in length to metatarsomeres 2-4 (Fig. 3); pretarsal claw bifid, rami equal in length. Wings. Wings in normal resting position above abdomen, forewings covering hind wings, making it impossible to observe latter and dorsal part of abdomen. Costal cell narrow, veins $\mathrm{C}$ and $\mathrm{R}$ separated by less than their combined width in middle of costal cell; vein $\mathrm{R}$ bent posteriorly at junction of $\mathrm{R}$ and $\mathrm{M}$, this junction separate from junction between $\mathrm{R}$ and Rs+M (Fig. 4), latter being slightly curved; abscissa of vein Rs well developed; vein $2 \mathrm{r}$ insert on Rs close to junction between Rs and 3r-m; angle between veins Cul and $1 \mathrm{~m}$-cu more than $120^{\circ}$, latter 

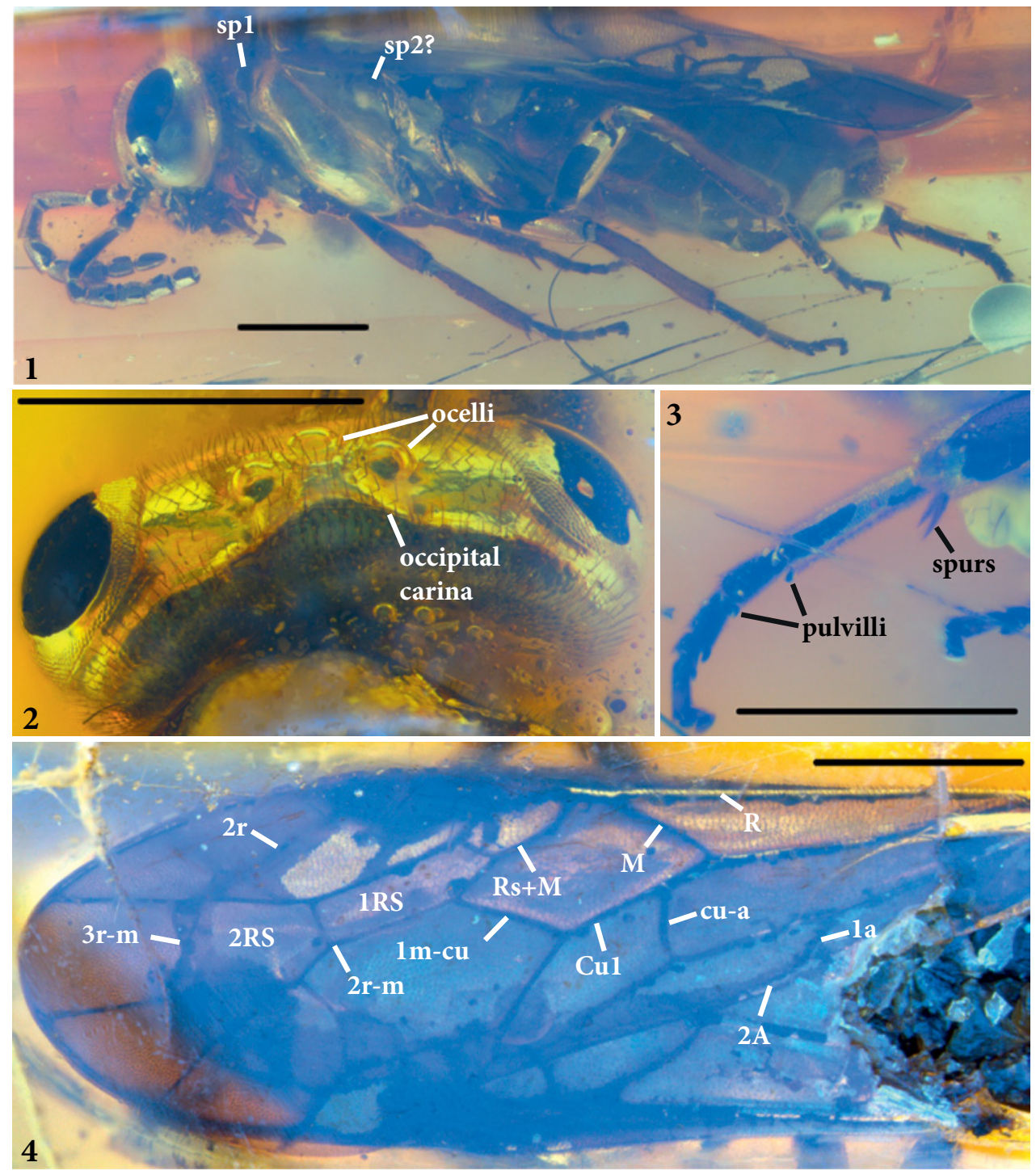

Figs 1-4. Sambia succinica gen. et sp.n. (1) Habitus, lateral view; sp1 and sp2 indicate anterior and posterior thoracic spiracle, respectively; (2) Head, dorsal view; (3) Right metatarsus, lateral view; (4) Left forewing. Scale bars=1 mm. This figure is published in colour in the online edition of this journal, which can be accessed via http://booksandjournals.brillonline.com/content/1876312x.

parallel with vein M (Fig. 4); veins $1 \mathrm{~m}$-cu and $2 \mathrm{~m}$-cu insert on different cells; both veins $2 \mathrm{r}-\mathrm{m}$ and $3 \mathrm{r}-\mathrm{m}$ present; proximal part of posterior anal vein $(2 \mathrm{~A})$ difficult to observe, apparent crossvein 1a oblique and distal in anal cell (Fig. 4), recurving vein $3 \mathrm{~A}$ might be present, but distal termination impossible to see. Abdomen. Abdominal tergum 1 could not be observed (see above); lateral parts of abdominal tergites accommodating spiracles continuous with dorsal parts. Ovipositor apparatus partly occluded, 
but outline of proximal parts (first and second valvifers, first and second valvulae) visible; cerci not observed.

\section{Etymology}

The specific epithet is based on "succinite", the term for Baltic amber, referring to its high succinic acid content and the Latin term succinum, meaning "amber".

\section{Discussion}

The placement of S. succinica in Tenthredininae is based on the combination of two forewing characters: the bend in vein $R$ distally and the junctions of veins $M$ and $\mathrm{Rs}+\mathrm{M}$ with vein $\mathrm{R}$ being some distance from each other (cf., Figs 5-8). Each character in isolation is shared by other members of the Tenthredinoidea, e.g., the bend in vein $\mathrm{R}$ by some Argidae and Diprionidae, the $\mathrm{M}-\mathrm{Rs}+\mathrm{M}$ configuration by Nematinae, most Selandriinae, and some Heterarthrinae (Vilhelmsen, unpubl.). However, the two traits are only very rarely observed together outside Tenthredininae. Furthermore, the presence of a dorsal occipital carina is rather uncommon outside this subfamily.

A number of characters were considered when trying to decide whether to place the fossil taxon in an extant genus or describe it as a new genus (condition in fossil in italics): The inner margins of the compound eyes (parallell converging); the configuration of the clypeus (straight/incurved); the presence of a dorsal (present) and lateral (absent) occipital carina; the configuration of the antenna (not clavate/subclavate); the inner margins of the propleura (separate/abutting); the relative length of the metatibial spur ( $1 / 3$ the length of the metabasitarsus/longer); the relative length of the metabasitarsus (shorter/longer than tarsomere 2-4); the relative widths of cells $1 \mathrm{RS}$ and 2RS in the forewing (1RS wider than 2RS/2RS wider than 1RS); the insertion of crossvein $\mathrm{cu}-\mathrm{a}$ on vein $\mathrm{Cu} 1$ in the forewing (1/3 from base/further away); the configuration of crossvein $1 \mathrm{a}$ in the forewing (absent/proximal, straight/distal, oblique (but see above)).

None of the extant genera examined provide a good match for S. succinica. Siobla resembles $S$. succinica in a number of features, but differs in having the lateral occipital carina present, the apical metatibial spur long, forewing cell 2RS wider than 1RS (compare Figs 4 and 5), and forewing crossvein cu-a inserting on $\mathrm{Cu} 1$ very close to $\mathrm{M}$. The only taxon having the occipital carina present dorsally but absent laterally like $S$. succinica is $A$. fulvipes, but it differs from the former in having non-clavate antennae, the medioventral propleural margins being separate, and having crossvein 1a in the forewing proximal and straight. If a recurving vein $3 \mathrm{~A}$ is present in the forewing of the fossil, this indicates that veins $2 \mathrm{~A}$ and $3 \mathrm{~A}$ might be discontinuous for some distance (see Fig. 8), a condition that is most developed in some specimens of Pachyprotasis. This genus differs from S. succinca in having a deeply incurved clypeus, an occipital carina present laterally as well as dorsally, the antenna elongate and not clavate, and the metatibial apical spur reaching half the length of the metabasitarsus. 

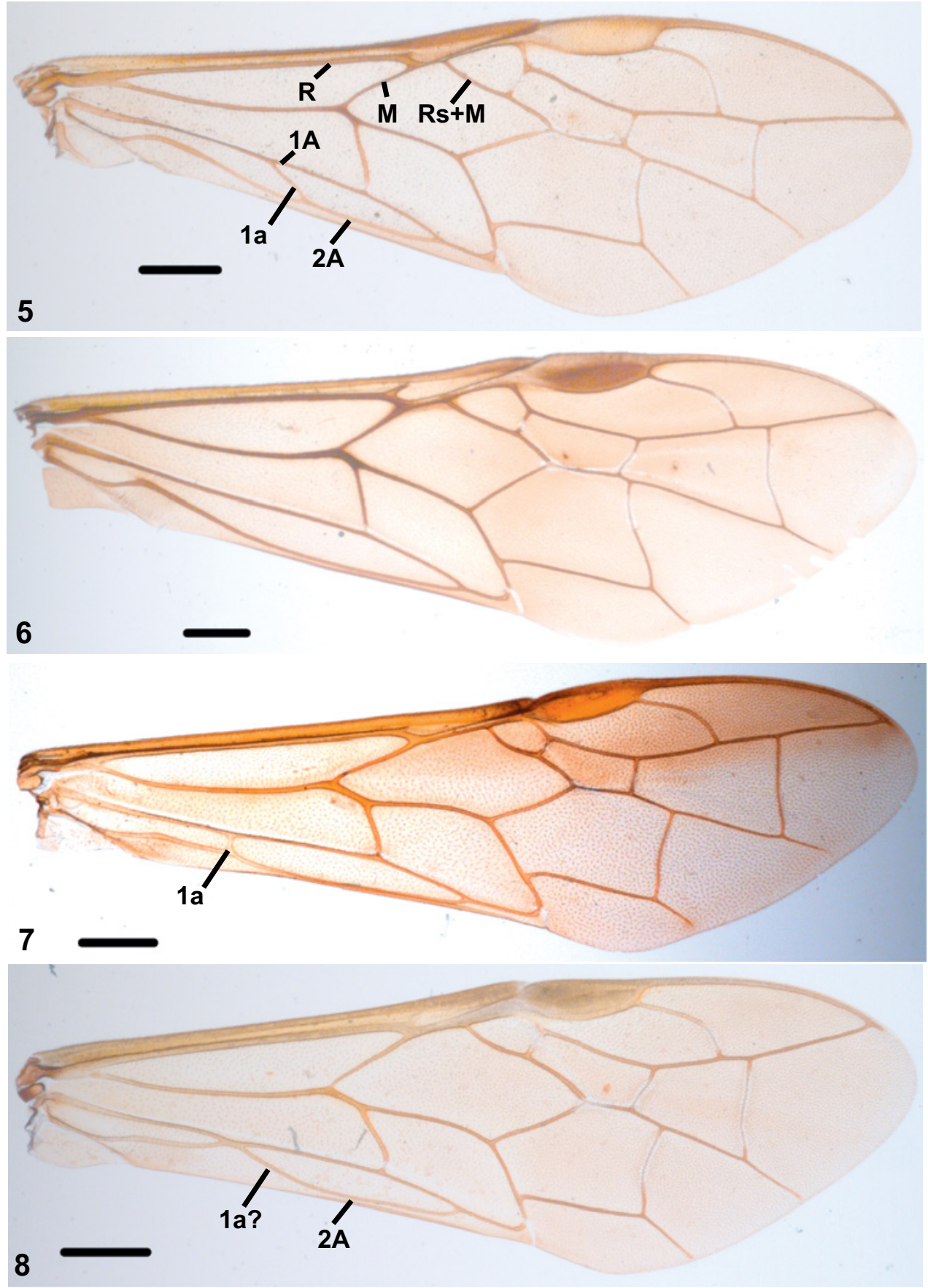

Figs 5-8. Forewings of extant Tenthredininae: (5) Siobla sturmii (Klug); (6) Corymbas koreana Konow; (7) Tenthredo scrophulariae Linnaeus; (8) Macrophya duodecimpunctata (Linnaeus). Scale bars=1 mm. This figure is published in colour in the online edition of this journal, which can be accessed via http:// booksandjournals.brillonline.com/content/1876312x. 
There is some variation in the configuration of the forewing anal veins among Tenthredininae. Corymbas (Fig. 6) has both veins 1A and 2A developed and has an incurvation in the latter as does Siobla, but crossvein 1a is absent, a configuration otherwise only observed in some Selandriinae. In Aglaostigma, Filacus, Lagium, Leucopelmonus, Rhogogaster, Sciapteryx, Tenthredo and Tenthredopsis, 1a is placed more proximally and in the incurvation of $2 \mathrm{~A}$ and $1 \mathrm{a}$ is consequently shortened and straight (Fig. 7). In Macrophya, Pachyprotasis, Perineura and Zaschizonyx, vein 2A is discontinuous with $3 \mathrm{~A}$ and two separate anal cells are formed (Fig. 8). It is possible that the proximal part of the vein delimiting the distal anal cell posteriorly is homologous with $1 \mathrm{a}$. Alternatively, 1a has been obliterated when the midpart of vein $2 \mathrm{~A}$ has been displaced anteriorly to merge with the midpart of $1 \mathrm{~A}$. In this case, the transformation from the condition observed in Siobla to that in Macrophya and others perhaps took place via an intermediate state like the one displayed by Aglaostigma and others.

Very little information that can be put in a phylogenetic context can be gleaned from the descriptions of the compression fossils putatively assigned to Tenthredininae (see Table 1). Most of the fossils (e.g., those from the Eocene-Oligocene boundary of Florrisant, CO, USA) were described approximately a century ago, preserve very few reliable characters, and no attempt has been made to put them in any phylogenetic context, assuming they are correctly assigned as to family. Zhelochovtzev and Rasnitsyn (1972) attempted to provide revised interpretations of a small set of Florissant tenthredinids, but again, few details outside of forewing venation are available and all except Florissantinus angulatus appear to belong to other subfamilies. Also, as compression fossils they are less likely to yield character information than amber inclusions. In addition, many of the older descriptions are rather cursory and often poorly or not at all illustrated (e.g., those of Brues, Cockerell, and Rohwer).

Of the characters discussed above, the configuration of the anal veins is the only one that most descriptions provide information on. The most common configuration, displayed by Macrophya adventitia, M. pervestuta, Nortonella typica, Tenthredo infossa, T. meunieri, T. miocenica, T. oblita, T. rhysia, T. saxorum, T. submersa and Tenthredoides plurilocellata, is the one also present in most extant Tenthredininae, i.e., veins $1 \mathrm{~A}$ and 2A separate and crossvein 1a short, straight, and placed proximally. Only Tenthredo petrae unequivocally has the plesiomorphic condition, oblique and distally placed crossvein 1a. Tenthredoides plurilocellata actually has two straight transverse veins in the anal cell of the right forewing: one proximal straight vein like all the taxa just listed, and one distal straight (' $\mathrm{a}_{2}$ ' in fig. 225A of Zhang 1989). The latter is probably best interpreted as a teratological feature as only one, proximal straight vein is observed in the anal cell of the left forewing of this fossil (compare figs 225A and B of Zhang 1989), and two transverse veins in the anal cell are not observed in any other Tenthredinoidea known to us.

It is, thus, not really possible to attempt to place any of the described compression fossils more precisely within the Tenthredininae, or to decide whether they should be placed in the subfamily at all. To achieve that, the fossils themselves will have to be re-examined. However, that is beyond the scope of this contribution. Regardless, 
Table 1. Nineteen fossil species putatively assigned to the Tenthredininae in Taeger et al. (2010) and those for which original descriptions were consulted for comparison with the current amber specimen.

\begin{tabular}{|c|c|c|}
\hline Taxon & Age & Locality \\
\hline \multicolumn{3}{|l|}{ Fossils considered herein } \\
\hline Macrophya adventitia Lewis, 1969 & Miocene & $\begin{array}{l}\text { Latah Formation, Washington } \& \\
\text { Idaho, USA }\end{array}$ \\
\hline Macrophya pervetusta Brues, 1908 & Eocene-Oligocene & Florissant, Colorado, USA \\
\hline Nortonella typica Rohwer, 1908 & Eocene-Oligocene & Florissant, Colorado, USA \\
\hline Taeniurites fortis Cockerell, 1917a & Eocene-Oligocene & Florissant, Colorado, USA \\
\hline Tenthredinites bifasciata Meunier, 1915 & Oligocene & Aix-en-Provence, France \\
\hline Tenthredo avia Brues, 1908 & Eocene-Oligocene & Florissant, Colorado, USA \\
\hline Tenthredo fenestralis Cockerell, 1927 & Eocene-Oligocene & Florissant, Colorado, USA \\
\hline Tenthredo infossa Brues, 1908 & Eocene-Oligocene & Florissant, Colorado, USA \\
\hline Tenthredo meunieri Taeger et al., 2009 & Oligocene & Rott, Germany \\
\hline Tenthredo miocenica Zhang \& Zhang, 1990 & Miocene & Shanwang, Shandong, China \\
\hline Tenthredo oblita Cockerell, 1917b & Eocene-Oligocene & Florissant, Colorado, USA \\
\hline Tenthredo petrae Zhang \& Zhang, 1990 & Miocene & Shanwang, Shandong, China \\
\hline Tenthredo rhysia Zhang, 1989 & Miocene & Shanwang, Shandong, China \\
\hline Tenthredo saxorum Rohwer, 1908 & Eocene-Oligocene & Florissant, Colorado, USA \\
\hline Tenthredo submersa Cockerell, 1907 & Eocene-Oligocene & Florissant, Colorado, USA \\
\hline Tenthredo toddi Cockerell, 1914 & Eocene-Oligocene & Florissant, Colorado, USA \\
\hline Tenthredoides pluriocellata Zhang, 1989 & Miocene & Shanwang, Shandong, China \\
\hline \multicolumn{3}{|l|}{ Fossils not considered herein } \\
\hline Tenthredo gervaisi Heer, 1861 & Oligocene & Aix-en-Provence, France \\
\hline Tenthredo primordialis Piton, 1940 & Paleocene & Menat, France \\
\hline
\end{tabular}

Note: Tenthredo meunieri Taeger et al., 2009 is a replacement name for T. fasciata Meunier, 1922. Tenthredo miocenica Zhang \& Zhang, 1990 was redescribed and refigured by Zhang et al. (1994).

S. succinica in mid-Eocene amber predates any of the aforementioned fossils and therefore represents the oldest, definitive record of the Tenthredininae.

\section{Acknowledgements}

We are grateful to Lars Krogmann who facilitated access to the specimen, to Ken Puliafico who provided advice on the imaging, and to Weiting Zhang for translating Chinese references. Stephan Blank, Dave Smith and Meicai Wei provided valuable suggestions for improvement of an earlier version of the paper.

\section{References}

Brischke, D. (1886) Die Hymenopteren des Bernsteins. Schriften der Naturforschenden Gesellschaft in Danzig 6: 278-279.

Brues, C.T. (1908) New phytophagous Hymenoptera from the Tertiary of Florissant, Colorado. Bulletin of the Museum of Comparative Zoology, Harvard College 51: 259-276. 
Cameron, P. (1887) Descriptions of new genera and species of East Indian Tenthredinidae. Transactions of the Royal Entomological Society of London 4: 87-92.

Cockerell, T.D.A. (1907) Some fossil arthropods from Florissant, Colorado. Bulletin of the American Museum of Natural History, New York 23: 605-616.

Cockerell, T.D.A. (1914) A new fossil sawfly from Florissant, Colorado. The Canadian Entomologist 46: 32 .

Cockerell, T.D.A. (1917a) New Tertiary insects. Proceedings of the United States National Museum 52: 373-384.

Cockerell, T.D.A. (1917b) Some fossil insects from Florissant, Colorado. Proceedings of the United States National Museum 53: 389-392.

Cockerell, T.D.A. (1927) Hymenoptera and a caddis larva from the Miocene of Colorado. The Annals and Magazine of Natural History (Series 9) 20: 429-435.

Grimaldi, D. \& Engel, M.S. (2005) Evolution of the Insects. Cambridge University Press, Cambridge, $\mathrm{xv}+755 \mathrm{pp}$.

Handlirch, A. (1907) Die fossilen Insekten und die Phylogenie der rezenten Formen: Ein Handbuch für Paläontologen und Zoologen. Engelmann; Leipzig, pp. 641-1120, +pls. 37-51.

Huber, J.T. (2009) Biodiversity of Hymenoptera. In: Foottit, R. \& Adler, P. (Eds) Insect Biodiversity. Blackwell, Oxford, pp. 303-323.

Larsson, S.G. (1978) Baltic amber - a palaeobiological study. Entomonograph 1: 1-192.

Lewis, S.E. (1969) Fossil insects of the Latah Formation (Miocene) of Eastern Washington and Northern Idaho. Northwest Science 43: 99-115.

Meunier, F. (1915) Nouvelles recherches sur quelques insectes des Plâtrières d'Aix en Provence. Verhandelingen der Koninklijke Akademie van Wetenschappen 18: 1-17.

Meunier, F. (1922) Über einige neue Insektenreste aus dem Aquitanien von Rott am Siebengebirge (Rheinpreußen) und drei bereits von Germar beschriebene Typen. Jahrbuch der Preussischen Geologischen Landesanstalt zu Berlin 42: 506-510.

Nyman, T., Roininen, H. \& Vuorinen, J.A. (1998) Evolution of different gall types in willow-feeding sawflies (Hymenoptera: Tenthredinidae). Evolution 52: 465-474.

Nyman, T., Widmer, A. \& Roininen, H. (2000) Evolution of gall morphology and host-plant associations in willow-feeding sawflies (Hymenoptera: Tenthredinidae). Evolution 54: 526-533.

Piton, L. (1940) Paleontologie du gisement eocene de Menat (Puy-de-Dom) (Flore et Faune). Memoires de la Societe d'Histoire Naturelle d'Auvergne 1: 1-303.

Rohwer, S.A. (1908) The Tertiary Tenthredinoidea of the expedition of 1908 to Florissant, Colo. Bulletin of the American Museum of Natural History 24: 591-595.

Ronquist, F., Klopfstein, S., Vilhelmsen, L., Schulmeister, S., Murray, D. \& Rasnitsyn, A.P. (in press) A total-evidence approach to dating with fossils, applied to the early radiation of the Hymenoptera. Systematic Biology, DOI:10.1093/sysbio/sys058.

Schulmeister, S. (2003) Simultaneous analysis of basal Hymenoptera (Insecta): introducing robust-choice sensitivity analysis. Biological Journal of the Linnean Society 79: 245-275.

Spahr, U. (1987) Ergänzungen und Berichtigungen zu R. Keilbachs Bibliographie und Liste der Bernsteinfossilien - Ordnung Hymenoptera. Stuttgarter Beiträge zur Naturkunde, Serie B (Geologie und Paläontologie) 127: 1-121.

Statz, G. (1936) Ueber alte und neue fossile Hymenopterenfunde aus den Tertiären Ablagerungen von Rott am Siebengebirge. Decheniana. Verhandlungen des Naturhistorischen Vereins der Rheinlande und Westfalens, Bonn 93: 256-312.

Taeger, A. \& Blank, S.M. (2010) ECatSym - Electronic World Catalog of Symphyta (Insecta, Hymenoptera). Program version 3.10, data version 36 (08.12.2010). Digital Entomological Information, Müncheberg.

Taeger, A., Blank, S.M. \& Liston, A.D. (2010) World Catalog of Symphyta (Hymenoptera). Zootaxa 2580: $1-1064$.

Vilhelmsen, L. (2001) Phylogeny and classification of the extant basal lineages of the Hymenoptera (Insecta). Zoological Journal of the Linnean Society 131: 393-442. 
Weitschat, W. \& Wichard, W. (2002) Atlas of plants and animals in Baltic amber. Friedrich Pfeil Verlag, Munich, $256 \mathrm{pp}$.

Weitschat, W. \& Wichard, W. (2010) Baltic amber. In: Penney, D. (Ed.), Biodiversity of Fossils in Amber from the Major World Deposits. Siri Scientific Press, Manchester, pp. 80-115.

Zhang, J.-F. (1989) Fossil insects from Shanwang, Shandong, China (in Chinese, with English summary). Shandong Science and Technology Publishing House, Jinan, 6+459 pp.+92 pls.

Zhang, J.-F. \& Zhang, X. (1990) New genus and new species of sawflies (Hymenoptera, Tenthredinidae) in Miocene from Shanwang, China (in Chinese, with English summary). Entomotaxonomia 12: 29-36.

Zhang, J.-F., Sun, B. \& Zhang, X. (1994) Miocene insects and spiders from Shanwang, Shandong (in Chinese, with English summary). Science Press, Beijing, v+298 pp.+44 pls.

Zhelochovtzev, A.N. \& Rasnitsyn, A.P. (1972) On some Tertiary sawflies (Hymenoptera: Symphyta) from Colorado. Psyche 79: 315-327. 